\title{
Effects of danazol on incidence of progesterone and oestrogen receptors in benign breast disease
}

\author{
CAMBYSE PANAHY, JOHN R PUDDEFOOT, ELIZABETH ANDERSON, GAVIN P VINSON, \\ COLIN L BERRY, MAURICE J TURNER, CHRISTOPHER L BROWN, ANTHONY W GOODE
}

\begin{abstract}
Results from a continuing clinical trial in benign breast disease indicate that danazol may induce progesterone receptors and that this effect persists after treatment. In women given danazol the number of biopsy specimens that were positive for progesterone receptors rose from 14 out of 31 before treatment to 23 out of 30 at the end of six months' treatment and remained raised at 21 out of 31 six months later. The number of biopsy specimens that were positive for oestrogen receptors rose transiently from eight out of 31 to 12 out of 30 and then fell to six out of 31 . A satisfactory clinical response was achieved in 26 of the 31 patients but was maintained in only 11 six months or more after the end of treatment. It was only in this group that a significant and longstanding increase in progesterone receptors was observed.

These findings suggest that in some women with benign breast disease who have been treated with danazol changes occur that may have long term benefit.
\end{abstract}

\section{Introduction}

Benign breast disease embraces a wide range of clinical, radiological, and pathological entities ${ }^{1}$ and is thought to reflect the response of the breast to an abnormal hormonal milieu..$^{2-4}$ If this were the principal aetiological factor then not only a fairly consistent hormonal abnormality but also a fairly uniform and symmetrical distribution of signs and symptoms within the breasts might be expected. This is not the case. An alternative explanation is that the principal defect lies in the target organ, which reacts abnormally to cyclic physiological changes in hormone concentrations. It is also possible that the two mechanisms could coexist.

Little information is available on the response of human breast tissue to hormonal manipulation. ${ }^{5}$ This is principally because in vivo studies have been hampered by the lack of a satisfactory and acceptable method for obtaining adequate serial samples. ${ }^{6}$ To overcome this problem we designed and developed an instrument that has enabled us to obtain sufficient material for serial receptor and histological analyses.

Danazol has been successfully used to treat benign breast disease, and the main objective of this study was to see whether it had any

The London Hospital Medical College, London E1 2AD

CAMBYSE PANAHY, FRCs, lecturer in surgery, surgical unit

COLIN L BERRY, FRCPATH, professor of morbid anatomy, department of morbid anatomy

CHRISTOPHER L BROWN, FRCPATH, consultant histopathologist

ANTHONY W GOODE, FRCS, reader in surgery, surgical unit

Department of Biochemistry, Medical College of St Bartholomew's Hospital, London EC1M 6BQ

JOHN R PUDDEFOOT, BSC, research technician

ELIZABETH ANDERSON, PHD, research assistant

GAVIN P VINSON, DSC, professor of biochemistry

Department of Radiology, The London Hospital, London E1 1BB

MAURICE J TURNER, FRCR, consultant radiologist

Correspondence to: Mr Panahy. effect on steroid hormone receptors in benign breast disease that could account for the favourable clinical response, which is maintained in some patients after treatment has been stopped.

\section{Patients and methods}

We are conducting a continuing open clinical trial of danazol in benign breast disease that has been approved by the district ethics committee. Patients are entered into the trial after at least two visits when explanatory notes are given and informed written consent obtained. The women in the trial are premenopausal patients over the age of 25 who present to a special benign breast disease clinic with painful or tender breasts, or both, not responding to simple measures including analgesics and severe enough to interfere with their daily activity or marital relationship, or both. Between September 1983 and March 1986, out of 403 potential patients, $39(9 \cdot 7 \%)$ met the above criteria and consented to enter the trial.

The extent and severity of breast nodularity in these patients ranged widely, and early in the study one asymptomatic patient with severe localised nodularity was also entered into the trial. Thirty one of the patients completed the study: 26 were premenopausal and five had had hysterectomies with conservation of the ovaries. Their mean ages were 36.6 years (range $25-49$ ) and 40.8 (range $25-45$ ), respectively. Three patients defaulted, one after the first and two after the second biopsy. They were excluded from this report owing to incomplete data. A further five patients were withdrawn because of suspected side effects of danazol.

Patients had taken no hormonal treatments or oral contraceptives for at least six weeks before the trial. Four had taken a combined oral contraceptive in the past and one was taking one when first seen; another was taking a progestogen only pill when first seen. One patient had had a 10 day course of danazol eight months previously and another a month's course of evening primrose oil two months before entering the trial.

\section{BREAST BIOPSY}

Breast biopsies were performed immediately before treatment; at six months, before danazol was tailed off; and at 12 months. Because of changes in the receptor concentration ${ }^{7}$ and histological appearance ${ }^{8}$ with the menstrual cycle biopsies were performed in the early follicular phase when this could be identified.

The most clinically affected part of the breast was chosen; subsequent biopsies were performed close to and parallel to the previous ones. Local anaesthesia was obtained with $1 \%$ lignocaine in $1 / 200000$ adrenaline; up to $20 \mathrm{ml}$ was used depending on the size of the breast. The anaesthetic was injected at the proposed site of entry with a 23 gauge needle and the area to be biopsied was then infiltrated as a wedge by a 20 gauge spinal needle; except for the discomfort experienced during infiltration patients felt either no pain or only mild discomfort during the procedure.

Two specimens were obtained through a $5 \mathrm{~mm}$ stab incision with a biopsy needle designed and developed by us at The London Hospital. The instrument is based on the Tru-Cut needle but the whole procedure can be performed with one hand, leaving the other free to steady the breast, guide the needle, and compress the breast into the opened groove before firing, so that a larger specimen is obtained. A special sliding guard determines the depth at which the biopsy is started and can be adjusted to start at any depth up to $10 \mathrm{~cm}$ from the skin surface. Two stops vary the length of the specimen from 17 to $47 \mathrm{~mm}$. Three sizes of interchangeable needles are available: small, medium, and large with outside diameters of $4 \cdot 0,5 \cdot 0$, and $5.5 \mathrm{~mm}$ with a biopsy groove cross section of $3.2 \times 1.7,4.0 \times 2.5$, and $4.5 \times 2.5 \mathrm{~mm}$, respectively. With a few exceptions early on in the trial when the small needle was used, all biopsy specimens were taken with the medium needle; this gave an adequate sample for histological examination and receptor analyses.

Immediately after the biopsy manual compression was applied and maintained for at least five minutes or until all oozing had stopped; a dry 
dressing was then applied. The direction and depth of the biopsy specimen was recorded for future reference. A scab formed within 48 hours, and the patients experienced only minimal discomfort during this period, rarely requiring analgesics despite their disease. Moderate bruising occurred only once, and no haematomas or other complications occurred. Samples for receptor analyses were put immediately in liquid nitrogen until assayed.

\section{TISSUE PREPARATION}

Oestrogen and progesterone receptor assays were performed by a single saturation dose method, ${ }^{9}$ which has been extensively validated inter alia by comparison with Scatchard analysis and gives an excellent correlation. ${ }^{10} \mathrm{This}$ method was recently described in detail. ${ }^{11}$ Concentrations of $\geqslant 5 \mathrm{fmol} / \mathrm{mg}$ protein were taken as positive.

\section{TREATMENT REGIMEN}

After biopsy treatment was started with a standard dose of danazol $100 \mathrm{mg}$ twice a day for six months; after the second biopsy it was tailed off over the next three weeks. In six cases this dose was slightly altered for therapeutic reasons.

\section{CLINICAL RESPONSE}

The overall clinical response was assessed on an empirical scale of one to six (table I). Patients were classified as having had a satisfactory response to treatment and a satisfactorily maintained response after treatment at six and 12 months, respectively, if they scored no more than three for pain, tenderness, or nodularity. A score of four or more for any of these three variables after a satisfactory response at six months was classified as a relapse.
TABLE III-Relation between clinical response and changes in progesterone receptor activity between initial biopsy and biopsy at 12 months

\begin{tabular}{|c|c|c|c|c|c|c|}
\hline \multirow[b]{2}{*}{12 Month biopsy: } & \multicolumn{2}{|c|}{ Maintained response } & \multicolumn{2}{|c|}{ Relapse } & \multicolumn{2}{|c|}{ No response } \\
\hline & Positive & Negative & Positive & Negative & Positive & Negative \\
\hline Initial biopsy: & & & & & & \\
\hline Positive & 3 & 0 & 6 & 1 & 1 & 3 \\
\hline Negative & 7 & 1 & 3 & 5 & $i$ & 0 \\
\hline
\end{tabular}

and the biopsy at 12 months according to the clinical response. The trend in the group that showed no response was the opposite of that in the group in which the response was maintained for 12 months.

Oestrogen receptors-During treatment the proportion of biopsy specimens positive for oestrogen receptors increased but this proved to be transient and by 12 months there was a net decline (table IV). There were also a few changes in the activity of oestrogen receptors between the initial biopsy and the biopsy at 12 months in all three clinical groups, with 19 of the 23

TABLE IV-Relation between clinical response and proportion (\%) of biopsy specimens positive for oestrogen receptors

\begin{tabular}{llll}
\hline & Initially & At six months & At 12 months \\
\hline $\begin{array}{l}\text { Satisfactory clinical response maintained } \\
\text { at 12 months }\end{array}$ & $3 / 11(27)$ & $5 / 11(45)^{\star}$ & $2 / 11(18)$ \\
$\begin{array}{l}\text { Satisfactory clinical response but relapsed } \\
\text { by 12 months }\end{array}$ & $\begin{array}{l}3 / 15(20) \\
2 / 5(40)\end{array}$ & $\begin{array}{l}6 / 14(43)^{\star} \\
1 / 5(20)\end{array}$ & $\begin{array}{l}3 / 15(20) \\
1 / 5(20)\end{array}$ \\
\begin{tabular}{l} 
No clinical response \\
\hline
\end{tabular}
\end{tabular}

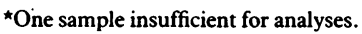

\section{Results}

Clinical response-Of the 31 patients who underwent three biopsies, 26 showed a satisfactory response at the end of six months' treatment. Six months later this response was maintained in 11 while 15 showed a relapse. Five patients failed to respond to treatment.

Progesterone receptors-Biopsy specimens were positive for progesterone receptors in 14 of the 31 patients initially, in 23 out of 30 after six months' treatment, and in 21 of the 31 at 12 months. Table II shows the results when these changes were analysed by clinical response. The increase in the proportion of biopsy specimens positive for progesterone receptors after six months' treatment was transient except in the group in which the clinical response was maintained, in which it was significantly raised at 12 months $(p=0.008$ by McNemar's test (one sided)). Table III shows the changes in activity of progesterone receptors that occurred between the initial biopsy

TABLE II-Relation between clinical response and proportion (\%) of biopsy specimens positive for progesterone receptors

\begin{tabular}{lccc}
\hline & Initially & At six months & At 12 months \\
\hline $\begin{array}{l}\text { Satisfactory clinical response maintained } \\
\quad \text { at } 12 \text { months }\end{array}$ & $3 / 11(27)$ & $7 / 11(64)$ & $10 / 11(91)$ \\
$\begin{array}{l}\text { Satisfactory clinical response but relapsed } \\
\text { by 12 months }\end{array}$ & $7 / 15(47)$ & $11 / 14(79)^{\star}$ & $9 / 15(60)$ \\
No clinical response & $4 / 5(80)$ & $5 / 5(100)$ & $2 / 5(40)$ \\
\hline
\end{tabular}

^One sample insufficient for analyses.
TABLE $\mathrm{V}-$ Relation between clinical response and changes in oestrogen receptor activity between initial biopsy and biopsy at 12 months

\begin{tabular}{|c|c|c|c|c|c|c|}
\hline \multirow[b]{2}{*}{12 Month biopsy: } & \multicolumn{2}{|c|}{ Maintained response } & \multicolumn{2}{|c|}{ Relapse } & \multicolumn{2}{|c|}{ No response } \\
\hline & Positive & Negative & Positive & Negative & Positive & Negative \\
\hline \multicolumn{7}{|l|}{ Initial biopsy: } \\
\hline Positive & 1 & 2 & 1 & 2 & $\mathbf{0}$ & 2 \\
\hline Negative & 1 & 7 & 2 & 10 & 1 & 2 \\
\hline
\end{tabular}

specimens that were negative for oestrogen receptors initially showing no change (table V).

\section{Discussion}

There is no consistent or convincing pattern to support the idea that the principal factor in the aetiology of benign breast disease is a hormonal abnormality. Luteal phase progesterone concentrations have been reported as low, normal, and high, and even though raised concentrations of free oestradiol have been reported, most workers have found normal oestrogen concentrations. Similarly, no clear abnormality of prolactin production has emerged. Androgen concentrations have been variously reported as low, normal, or high, and estimations of luteinising hormone, follicle stimulating 
hormone, and thyroid stimulating hormone concentrations remain equivocal. ${ }^{12}$

Steroid receptor concentrations in the normal breast and in benign breast disease differ. Oestrogen receptors are virtually undetectable in the normal breast ${ }^{13-16}$ and are low in benign breast disease, ${ }^{17}$ the incidence and content of these receptors paralleling the intensity of hyperplasia. ${ }^{16}$ On the other hand, progesterone receptor concentration is lower in benign breast disease than in the normal breast. Concentrations greater than $10 \mathrm{fmol} / \mathrm{mg}$ protein have been found in only $12 \%$ of breasts with benign breast disease compared with $33 \%$ of normal breasts and the incidence of positive progesterone receptor concentrations in benign breast disease has been reported to be as low as $12 \cdot 5 \% .{ }^{18}$

Danazol, a synthetic derivative of ethisterone, has been successfully used to treat benign breast disease since the first report of its therapeutic effect in $1971 . .^{19}$ It is thought to act centrally, on the hypothalamus and pituitary, and peripherally on target organs, binding with steroid receptors and affecting steroidogenesis ${ }^{20}$ and plasma proteins. ${ }^{21}$ After treatment with danazol is stopped patients with benign breast disease may show a clinical response lasting for six months or more. ${ }^{22}$ As all hormonal variables return to pretreatment concentrations within four weeks of danazol being stopped $^{23}$ this finding would be difficult to explain unless some longstanding changes had taken place. It has been suggested that the principal effect of danazol in benign breast disease could be peripheral and could take precedence over any central action. ${ }^{6}$ A similar local progestin-like effect rather than a systemic one may be responsible for the therapeutic effect of danazol on the endometrium. ${ }^{24}$

Progesterone receptors that are independent of oestrogen can be induced by antioestrogens $\mathrm{s}^{25}$ and "active" serum ${ }^{26}$ in breast cancer cell lines and tamoxifen in mammary cancer. ${ }^{27}{ }^{28}$ The data presented here suggest that danazol may affect steroid receptors in benign breast disease, being associated with a rise in the proportion of biopsy specimens positive for both oestrogen and progesterone receptors after six months' treatment. Whereas the changes in oestrogen receptor concentration proved to be transient the number of samples that were positive for progesterone receptors at 12 months remained above the pretreatment number in those patients who responded to treatment. Induction of progesterone receptors could result in the breast becoming more sensitive to progestins ${ }^{28}$; interestingly, induction of progesterone receptors at 12 months was significant only in the 11 patients whose clinical response was also maintained six months or more after treatment. These findings could indicate long term, if not permanent, changes in a subgroup of patients with benign breast disease that theoretically could be beneficial.

The clinical trial is generously funded by Winthrop Laboratories. We are grateful to Professor H D Ritchie, emeritus professor of the University of London, whose encouragement and support made this trial possible, and to Mr R Worpole for designing and producing the breast biopsy instrument.

\section{References}

1 Preece PE. Nomenclature of benign breast disease, with particular reference to national differences in approach. In: Baum M, George WD, Hughes LE, eds. Benign breast disease. London: Royal Society of Medicine, 1983:3-6. (International Congress and Symposium Seric No 76.)

2 Sherman BM, Korenman SG. Inadequate corpus luteum function: a pathophysiologica interpretation of human breast cancer epidemiology. Cancer 1974;33:1306-12.

3 Sitruk-Ware LR, Sterkers N, Mowszowicz I, Mauvais-Jarvis P. Inadequate corpus luteum function in women with benign breast disease. $\mathcal{F}$ Clin Endocrinol Metab 1977;44:771-4.

4 Reed MJ, Cheng RW, Noel CT, Dudley HAF, James VHT. Plasma levels of estrone, estrone sulphate and estradiol and the percentage of unbound estradiol in postmenopausal women with sulphate and estradiol and the percentage of unbound es

5 Hughes LE, Mansel RE. Benign breast disease. In: Russell RCG, ed. Recent advances in surgery. Edinburgh: Churchill Livingstone, 1982:101-28.

6 Gorins A, Perret F, Tournant B, et al. Double-blind crossover trial of danazol and placebo in the treatment of severe fibrocystic breast disease. Gynecologie 1983;34:351-7.

7 Kutten F, Fournier S, Durand JC, Mauvais-Jarvis P, Baudot N, Doukani A. Oestradiol and progesterone receptors in human breast fibroadenoma. I Clin Endocrinol Metab 1981;52: $1225-9$.

8 Vogel PM, Georgiade NG, Fetter BF, Vogel FS, McCarthy KS. The correlation of histologic changes in the human breast with the menstrual cycle. Am $\mathcal{F}$ Pathol 1981;104:23-4.

9 King RJB, Redgrave S, Hayward JL, Millis RR, Rubens RD. The measurement of receptors for oestradiol and progesterone in human breast tumours. In: King RJB, ed. Steroid receptor assays in human breast tumours: methodological and clinical aspects. Cardiff: Alpha-Omega Publishing, 1979:55-72.

10 Puddefoot JR, Anderson E, Vinson GP, Gilmore OJA. Heterogeneity of oestrogen receptors in human breast tumours. $\mathcal{F}$ Endocrinol 1986;108(suppl): 105.

11 Panahy C, Puddefoot JR, Anderson E, et al. Oestrogen and progesterone receptor distribution in the cancerous breast. Brf Cancer 1987;55:459-62.

12 Wang DY, Fentiman IS. Epidemiology and endocrinology of benign breast disease. Breast Cancer Res Treat 1985;6:5-36.

13 Johansson $H$, Terenius $L$, Thoren $L$. The binding of estradiol $17 \beta$ to human breast cancer and other tissue in vitro. Cancer Res 1970;30:692-8.

14 Terenius L, Johansson H, Rimsten A, Thoren L. Malignant and benign human mammary disease: estrogen binding in relation to clinical data. Cancer 1974;33:1364-8.

15 Rosen PP, Menendez-Botet CJ, Nisselbaum JS, et al. Pathological review of breast lesions analyzed for estrogen receptor protein. Cancer Res 1975;35:3187-94.

16 Jacquemier JD, Rolland PH, Vague D, Lieutaud R, Spitalier JM, Martin PM. Relationships between steroid receptor and epithelial cell proliferation in benign fibrocystic disease of the between steroid receptor and
breast. Cancer 1982;49:2534-6.

17 Allegra.JC, Lippman ME, Green L, et al. Estrogen receptor values in patients with benign breast disease. Cancer 1979;44:228-31.

18 Lloyd RV. Studies on the progesterone receptor content and steroid metabolism in normal and pathological human breast tissues. F Clin Endocrinol Metab 1979;48:585-93.

19 Greenblatt RB, Dmowski WP, Mahesh VB, Scholer HFL. Clinical studies with an antigonadotropin-danazol. Fertil Steril 1971;22:102-12.

20 Barbieri RL, Ryan KJ. Danazol: endocrine pharmacology and therapeutic applications. Am $\mathfrak{f}$ Obstet Gynecol 1981;141:453-63.

21 San Filippo JS, Barrows GH, Apkarian RP, Wittliff JL. Evaluation of danazol influence upon the uterus using scanning electron microscopic morphometric and biochemical analyses. Surg Gynecol Obstet 1985;160:421-8.

22 Pye JK, Mansel RE, Hughes LE. Clinical experience of drug treatments for mastalgia. Lancet 1985;ii:373-7.

23 Bohnet HG, Hanker JP, Schweppe KW, Schneider HPG. Changes of prolactin secretion following long-term danazol application. Fertil Steril 1981;36:725-8.

24 Kokko E, Janne O, Kauppila A, Ronnberg L, Vihko R. Danazol has progestin-like actions on the human endometrium. Acta Endocrinol (Copenh) 1982;99:588-93.

25 Eckert RL, Katzenellenbogen BS. Effects of estrogens and antiestrogens on estrogen receptor dynamics and the induction of progesterone receptor in MCF-7 human breast cancer cells Cancer Res 1982;42:139-44.

26 Devleeschouwer N, Olea-Serrno N, Leclerq G, Legros N, Heuson JC. Induction of progesteron receptor in an estrogen, progesterone receptor negative-breast cancer cell line. 7 Steroid Biochem 1986;24:365-8.

27 Harland RN, Hayward E, Barnes D, Howell A, Selwood RA. Induction of progesterone receptor by tamoxifen as an indication of endocrine response in mammary carcinoma. $\mathrm{Br} \mathcal{J}$ Surg 1983;70:685.

28 Iacobelli S, Natoli C, Natoli V, Gentiloni N, Marchetti P, Frate L. Steroid hormone receptors and other factors in predicting response to endocrine therapy in breast cancer. In: Lanius $P$, ed. other factors in predicting response to endocrine therapy in breast cancer. In: Lanius P, ed.
Proceedings of German-Italian oncological symposium No 1. Freiburg: Kehrer Offset, 1982:31-90.

(Accepted 23 June 1987) 